\title{
THE ROYAL SOCIETY OF EDINBURGH
}

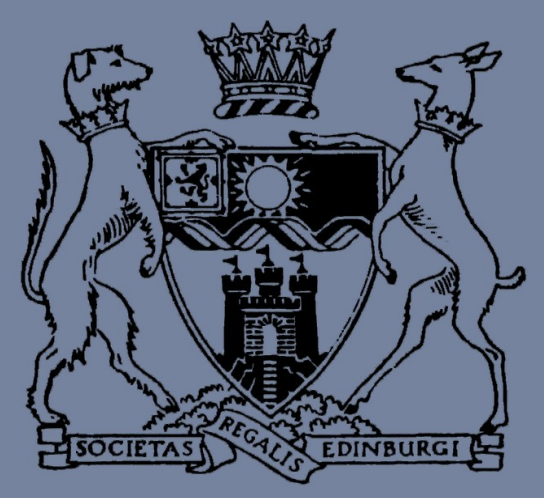

\section{PROCEEDINGS Section A (Mathematics)}

ISSN $0308-2105$

PUBLISHED BY THE ROYAL SOCIETY OF EDINBURGH 22 GEORGE STREET, EDINBURGH, EH 22 PQ

1979 


\section{EDITORIAL BOARD}

\section{Executive Editors}

J. DUNCAN

University of Stirling

A. JEFFREY

W. N. EVERITT

University of Dundee

University of Newcastle upon Tyne

T. S. BI.YTH

University of St Andrews

W. D. Collins

University of Sheffield

P. HeYwoon

University of Edinburgh

D. S. JONES

University of Dundee

R. J. KNOPS

Heriot-Watt University

R. M. S. SMELI.IE:

General Secretary

Royal Society of Edinburgh
J. B. MCLrod

University of Oxford

W. D. MunN

University of Glasgow

E. M. Pattrerson

University of Aberdeen

R. A. RANKIN

University of Glasgow

G. F. ROACH

University of Strathclyde

W. H. RUTHERFORD

Executive Secretary

Royal Society of Edinburgh

\section{Consulting Editors}

H. AMANN

Universität Zürich

F. M. ArscotT

University of Manitoba

F. V. AtKInson

University of Toronto

H. BREZIS

Université de Paris VI

J. W. S. Cassels

University of Cambridge

R. ContI

Istituto Matematico, Firenze, Italy

W. A. Coppres.

Australian National University

M. S. P. Eastham

Chelsea College, London

D. E. EDmunds

University of Sussex

AvNer Friedman

Northwestern University, Evanston,

Illinois, USA

J. K. HAI.E

Brown University, Providence, RI, USA

P. R. Halmos

University of Indiana, Bloomington, USA

E. M. DE. JAGER

Universiteit van Amsterdam
Tosio Kato

University of California, Berkeley, USA

J. KuRZWEIL

Matematický ústav ČSAV, Praha,

Czechoslovakia

J. Mawhin

Université Catholique de Louvain

A. PAZY

The Hebrew University of Jerusalem

ĂKF: PleiJfi

University of Uppsala, Sweden

G. B. Preston

Monash University, Clayton, Australia

G.-C. Rota

Massachusetts Institute of Technology, USA

F. STUMmel

Johann Wolfgang-Goethe University,

Frankfurt am Main, Germany

F. URSELLL

University of Manchester

P. WALTMAN

University of Iowa

W. WENDLAND

Technische Hochschule Darmstadt

J. WERMER

Brown University, Providence, RI, USA

A. ZEITL

Northern Illinois University,

De Kalb, Illinois, USA 